\title{
INTEREST RATE DEREGULATION AND THE PERFORMANCE OF DEPOSIT MONEY BANKS IN NIGERIA FROM 1989-2020
}

\section{Ekponaanuadum Nwinee ${ }^{1}$ and Kenigheni Good-Wilson (Ph.D) ${ }^{2}$}

Captain Elechiamadi Polytechnic, Rumuola, Rumuolumeni, Port Harcourt.

${ }^{1}$ Email: nwineeekpo4@gmail.com; Tel: 08037067166

2Email: kenigheniwilson@gmail.com; Tel: 08059075757

\section{Cite this article:}

Ekponaanuadum N.,

Kenigheni G. (2021), Interest Rate Deregulation and the Performance of Deposit Money Banks in Nigeria from 1989-2020. African Journal of Economics and Sustainable Development 4(2), 86-95. DOI: 10.52589/AJESDSD66UCR6.

\section{Manuscript History \\ Received: 5 May 2021 \\ Accepted: 5 May 2021 \\ Published: 9 Aug 2021}

Copyright $(92020$ The Author(s). This is an Open Access article distributed under the terms of Creative Commons AttributionNonCommercial-NoDerivatives 4.0 International (CC BY-NC-ND 4.0 ), which permits anyone to share, use, reproduce and redistribute in any medium, provided the original author and source are credited.

\begin{abstract}
The research examined interest rate deregulation and the performance of deposit money banks in Nigeria for the period of 1989-2020. The objective of the study is to examine the impact of interest rate deregulation on the performance of deposit money banks in Nigeria and to examine the causal relationship between interest rate deregulation and performance of deposit money banks in Nigeria. The estimation output of the research shows a positive relationship between interest rate and bank performance in Nigeria measured by Total Assets of Deposit money banks in Nigeria. The coefficient of determination (67\%) also shows above average explanatory power of the independent variables on the dependent variable. The results of the study show a long and short run relationship between the dependent variable (Total Assets) and the independent variables (Interest rate, inflation rate, loans and advances). The result also shows unidirectional causality between Total Assets and Loans and Advances. The research recommended among others that the $C B N$ should consider not frequently changing the MPR (monetary policy rate) and CRR (Cash reserve ration) which most of the time influence interest rate peg of the deposit money banks.
\end{abstract}

KEYWORDS: Interest Rate, Deregulation Policy, Deposit Money Banks, Total Assets, Banks’ Performance. 


\section{INTRODUCTION}

Interest rate deregulation as conceived and implemented by the Nigerian government was aimed at opening up the banking sector to high private sector participation to drive the economy positively. But since the commencement of the policy in 1989, the banking sector has not shown any improvement linked to deregulation, rather improvements in the sector are mainly from other policy actions of the Central Bank of Nigeria (CBN). The performance of the deposit money banks in Nigeria largely depends on total savings deposits in the sector and that is the main reason banks set their staff on a high target of deposits to sustain their operations. Although, officially the banks are under deregulation policy, interest rate in Nigeria is still indirectly regulated. The monetary policy rate (MPR) which the Central Bank uses to control interest rate still determines the direction of interest rate flow in deposit money banks in Nigeria. A higher MPR means interest rate will be high and vice versa. Presently the MPR is $14 \%$ according to CBN (2018). The implication is that banks in Nigeria cannot afford to lend at single digit rate because the total loans of the banks are not determined by bank savings rate, which ought to have influenced total customer deposits to a high trajectory but the rate at which banks borrow from CBN via MPR. The cash reserve ratio and liquidity ratio which the central Bank uses mainly to ensure stability and reduction of risk in the banking sector also exerts high influence on how interest rates are determined by the deposit money banks in Nigeria. In the ideal banking sector, the performance of bank loans and interest rate margin determine the growth of the sector.

The market risk posed by interest rate volatility also goes beyond the performance of these banks to influence the flow of economic activities in an economy including considerable influence on inflation rate, and performance of the real sector mainly agriculture and manufacturing sectors which the economy depends on to generate employment and revenue for economic wellbeing of the nation. Banks in their bid to enhance business, tend to manipulate the savings rate to increase deposits, but in reality, greater percentage of deposits in the Nigerian banks are not basically because of the savings rate, but due to increase in financial literacy in the country and governments revenues often traced to the banks.

Interest rate differs from bank to bank in the nation and also differs in the same bank based on customers' credit records. The prime rates are given to the most preferred customers who have a positive track record with the banks while maximum lending rates are open to all who can meet the criteria. Such has also made access to the benefits of the deregulation policy difficult for a large number of people. This study used empirical methods to analyze the impact of interest rate deregulation on the performance of deposit money banks in Nigeria, so as to help direct the monetary policy authorities in Nigeria on how best to approach interest rate policies. Such will reposition the banking sector for a greater economic benefit. This study seeks to examine the impact of interest rate deregulation on the performance of deposit money banks in Nigeria, as well as to examine the causal relationship between interest rate deregulation and performance of deposit money banks in Nigeria. This paper is divided into five sections, viz; introduction, literature review, methodology, results and discussion, and conclusion and recommendations. 


\section{REVIEW OF LITERATURE}

\section{Theoretical Literature}

\section{(a) Loan-able funds Theory}

Loan-able fund is a neo-classical theory of interest rate, developed by the likes of Ohlin, Myrdal and Robertson. The theory states that interest rate is determined by the forces of demand and supply of loan-able funds. The theory further explains the purpose of demands for loan-able funds which are (i) investment (ii) Hoarding and (iii) di s-saving. For investment, the theory explains the inverse relationship between demand for loan-able funds and interest rate. An investor desires for funds to invest in making of new capital goods, but such demand can only be actualized if the interest rate is less compared to the expected return on investment. If the interest rate is less, the demand will be high and if the interest rate is high, the demand will be low. For hoarding, the theory explains that the desire for liquidity triggers hoarding by some people and this has an inverse relationship with interest rate. Same inverse relationship still exists in dis-saving. For supply of loan-able funds, the theory explains it under savings, dishoarding, disinvestment and bank credit. For savings, the theory explains that people will save more with high interest rate and less with low interest rate. Such a positive relationship was also utilized to explain dishoarding and disinvestment. Bank credit is also explained as it affects loan-able funds. Since the banks also create credit when they lend money out. The theory concludes that interest rate is determined by the point of equilibrium between demand for and supply of loan-able funds.

(b) Structure, conduct, performance paradigm explains relationship between market structure, market conduct and market performance. The model explains the buyers' and sellers' relationship as it relates to product, structure, conduct and performance of an establishment. Firms strategically choose behaviors, investment and total enhancement to better business, thus to assess performance. The model explains that ratios are utilized at price, quantity, product quality and efficiency.

\section{Empirical Literature}

Afza, Raja, Imran \&Saima (2018) on Interest Rate and Financial Performance of Banks in Pakistan employed Correlation and Regression analysis on interest rate changes, deposits with other banks, advances and loans and investment; return on assets, return on equity and earnings per share. The result shows that deposits with other banks and interest rates are negatively affecting the profitability of banks, while advances and loans and investment are having a positive influence over profitability of banks. The research recommended that the Government should make monetary policies which will increase the profitability of banks. But such policies were not defined.

Alhassan, Anokye and Gakpetor (2018) on effect of interest rate spread on the profitability of commercial banks in Ghana. The research is based on a sample of 24 banks over a ten - year period using panel data, interest rate spread, net interest margin Return on Assets and Return on Equity were the data for the study. The study shows that there is a positive and statistically significant association between interest rate spread and bank profitability in Ghana. The research recommended that policies aimed at reducing interest rate spread in Ghana should focus on making credit facilities available at a cheaper rate to compel commercial banks to reduce interest rate. 
Egbetunde, Ayinde and Balogun (2017) on Interest Rate Liberalization, Financial Development and

Economic Growth in sub-Saharan African Economies, employed panel data cointegration and error correction model. The research shows that trade openness and price stability exert greater significance on the economic growth of Sub-Saharan Africa economy than interest rate. Interest rate was shown to have a negative relationship with the dependent variable which is the gross Domestic Product.

Makinde (2016) on the effect of interest rate on commercial banks deposits in Nigeria, applied the ordinary least square method to establish an empirically based output. The study reveals that interest rate is not the cause of costumer's deposits in banks. Thus, it stated that there is a negative relationship between interest rate and deposits in commercial banks. The study advocated for financial literacy to help boost deposits in banks. Ubesie (2016) researched on the effect of financial sector liberalization on economic growth in Nigeria, applied the vector Error Correction Model to assess the direction of the effect of liberalization policy on the economic growth rate of the nation. The research utilized variables such as gross domestic product, interest rate, inflation and exchange rate. The independent variables in the estimation result show a $92 \%$ explanatory power on the dependent variable. Thus, the research concluded that liberalization has a positive effect on economic growth of Nigeria.

Guesmi (2015) researched the impact of financial liberalization on the performance of the Algerian public banks, applied a panel data analysis method using data from five banks in Algeria. The research findings shows that size of intermediation and concentration of banks have a positive impact on the banks whilst interest rate does not have such impact on banks.

Eke, Eke and Inyang (2015) on interest rate and commercial banks' lending operations in Nigeria. The study performed a comparative study of two interest rate regimes in Nigeria, thus the regulated and the deregulated period. For regulated periods, it was found that interest rates have a negative relationship with bank loans whilst in the deregulated era, it was shown that there exist inelastic relationships between interest rate and loans of commercial banks. The research thus suggested that a revised version of deregulation should be developed with Monetary policy rate (MPR) used as a control tool.

Manamba (2014) on empirical analysis of interest rate spreads in Tanzania, investigated the volatility of the interest rate since the liberalization policy of 1991 in Tanzania. The research findings show that interest rate spreads are higher after liberalization than before the policy period. The research also shows that poor competition also affects interest rate spread in Tanzania. The research recommended building liquid assets for banks to help curtail interest rate and risk.

Matemilola, Bany-Ariffin and Muhtar (2014) in a study on the impact of monetary policy on banks' lending rate in South Africa applied a threshold autoregressive and asymmetric error correction model. The study which aims at assessing the financial sector reforms in South Africa found out that commercial banks put measures to lower interest rates but it appears to be upward permanently. The study then recommended a transparent and further developed banking system in South Africa.

Odeke and Odongo (2014) on Interest Rate Risk Exposure And Financial Performance of Commercial Banks in Uganda, utilized a cross sectional survey and descriptive research design 
with a sample size of 9 commercial banks analyzed and interpreted using financial ratios of DuPont analysis of commercial banks. The research findings show that a combined variation of maturity gaps, basis risk and assets and liabilities margins for all the commercial banks accounted for up to $14.9 \%$ variation in their banks performance. The variation explained $20.19 \%$ of the performance of the commercial banks. The overall analysis of interest rate risk exposure and bank performance showed generally a positive relationship except basis risk. It recommended that Commercial Banks need to develop policies and resources to manage asset and liability duration mismatches effectively. Such a recommendation is directionless. Udoka, Agwenjang and Arzizeh (2012) on Empirical Analysis of the Effect of Interest Rate Management Policies in Nigeria employed Ex-post facto research design to analyze the data. The data employed for the research are interest rate and Gross Domestic Product. The research shows that there exists an inverse relationship between interest rate and economic growth in Nigeria that hinders growth of the real sector. They recommended that a strong monetary policy for Nigeria should be initiated that would enhance lending to the real sector economy of Nigeria for the sustenance of economic activities. The research ended without giving any specific monetary policy that should be employed to achieve the specified goal. Ugwuanyi (2012) studied Interest Rate Deregulation and Bank Lending in Nigeria to show the relevance of the hinges on the fact that credit and its costs (interest) perform a private role in shaping the economic future of Nigeria. The ordinary least squares (OLS) techniques were employed using data such as Bank Lending, Money Supply, Interest Rate, Marginal rediscount Rate, Total Bank Deposit and Inflation Rate.

The research found a significant relationship between the dependent variable and the independent variables. Thus, the research recommended that the government through the Central Bank should implement stringent fiscal and monetary policies aimed at reducing inflation. The research methodology was poorly developed and recommendations do not show any significant contribution of the research to the society.

\section{Research Design}

The ex-post facto research design was adopted for this research. It shows the effective relationship between the variables, the dependent and independent.

\section{Model Specification}

The functional relationship which is a multiple regression is as follows:

$\mathrm{TA}=\mathrm{f}(\mathrm{INT}, \mathrm{INFL}, \mathrm{LD})$

The Econometrics model is specified as follows:

$\mathrm{TA}=\mathrm{pO}+\mathrm{P} 1 \mathrm{INT}+$

P2INFL + P3LD + p

Where: $\mathrm{TA}=$ Total Assets of

banks INT=Interest rate

(Prime lending rate)

INFL=Inflatio

$\mathrm{n}$ rate $\mathrm{LD}=$

loans and 
Advances

$\mathrm{PO}$, pi, $\mathrm{P} 2$ and $\mathrm{P} 3=$ parameters and

$\mathrm{p}=$ Stochastic Error term A Priori expectations

are: $\mathrm{p} 1, \mathrm{P} 2,>0$ and $\mathrm{P} 2<0$.

\section{Explanation of the Data Used}

(i) Total Assets of banks is used to measure the total value of the deposit money banks as to ascertain the performance of the banks.

(ii) Interest rate -the choice of prime lending rate to maximum lending rate is to ascertain on the average the effect of interest rate on the performance of commercial banks in Nigeria. It shows the average interest charged by the lender to the borrower for the use of its financial facilities usually measured in percentage.

(iii) Inflation measures the general increase in price of commodities in a given economy. The addition of inflation in the model as a control variable is because it assesses the purchasing power or value of money in the economy.

(iv) Loans and Advances measures the debt and credit facilities granted by the deposit money banks in Nigeria for a short and long period.

\section{Method of Evaluation}

The ordinary least square method was used for data analysis. The entire test was conducted at $5 \%$ level of significance. The first test is the Augmented Dickey-Fuller (ADF) test for stationarity. The test model is; $\mathrm{yt}=\mathrm{c}+\mathrm{P} 1 * \mathrm{t}+\mathrm{cp}$ yt $-1+0 £ \mathrm{t}-1+£ \mathrm{t}$

\section{Decision rule}

If $\mathrm{p}$-value < level of significance (0.05); then null hypothesis is rejected.

If $\mathrm{p}$-value > level of significance (0.05); then we fail to reject the null hypothesis.

The second step is the Bound test for cointegration, the rule of the bound test states that if the f-statistic is higher than the lower bound and upper bound, that there is cointegration.

Empirical Model: TA=f (INT, INFL, LD)

The Bound cointegration test model:

Where:

$\mathrm{C}=$ Constant

TA=Total Assets of banks

INT=Interest rate (Prime lending rate)

INFL=Inflatio

$\mathrm{n}$ rate $\mathrm{LD}=$

loans and 
Advances

$\mathrm{P}=$ optimum

lag length

The ECM -Error Correction mechanism is also conducted to establish the short run relationship, it is expected to be negative and most of the time, less than 1. Finally, the predictive power of the variables was tested using the Granger Causality test.

\begin{tabular}{|l|l|l|l}
\hline Variables & ADF Test statistics & $\mathbf{5 \%}$ Critical value & Order of inte \\
\hline TA & -3.714094 & -3.587527 & KD \\
\hline INT & -3.016389 & -1.957204 & Id) \\
\hline INFL & -2.108824 & -1.953381 & 1(0) \\
\hline LD & -5.322530 & -3.603202 & Id) \\
\hline
\end{tabular}

\section{The Augmented Dickey Fuller (ADF) test. Unit Root Test}

The ADF test for stationarity at 5\% level of significance shows that Total Assets, Interest rate and Loan and Advances are stationary at first difference, hence at 1 (1) while inflation is stationary at levels form $1(0)$.

\section{The Co-integration Test}

According to Pesaran, Shin and Smith (2001), Bound testing technique can be used to test for co-integration in a mixture of variables of order 1(0) and 1(1). If the F-statistic is greater than the lower and upper bound, at chosen level of significance then we conclude that there is cointegration, hence long run relationship.

The Bound test output shown above, shows that the F-statistic is 6.757675 which is greater than 4.35 , the upper bound at $5 \%$ of significance. Going by the rules of the co-integraion of mixed orders according to Pesaran, Shin and Smith (2001), we conclude that there is long run relationship between the variables then proceed to estimate the Error Correction mechanism (ECM).

\section{Error Correction Mechanism (ECM)}

From the result above, the ECM is negative which means that the model is acceptable. The speed of adjustment to equilibrium is $15 \%$. A change in interest rate will cause the Total Assets of the banks to increase by 6.524661 which is in line with apriori-expectation. A change in loans and Advances of banks will also lead the Total Assets to increase by 1.194835. Inflation is negatively related to Total Assets as a change in Inflation leads to Total Assets to decrease by 0.303402 . T-Statistics test shows that Loans and Advances are statistically significant at a P-Value of 0.0000 , while the F-Statistics test shows that the variables are jointly significant at $\mathrm{P}$-Value of 0.000026 . The goodness of fit test shows that the independent variables explain $67 \%$ changes in the dependent variable. We then proceed to estimate the forecasting power of the variables using Granger Causality Test. 


\begin{tabular}{|l|l|l|l|l|}
\hline Pairwise Granger Causality Tests & & \multicolumn{3}{|l|}{} \\
\hline Date: 26/01/20 Ume: 16:29 & & \multicolumn{2}{|l|}{} \\
\hline Sanmle: 19902018 & & & \\
\hline Lass: 2 & & & & \\
\hline & Obs & F- Statistic & Prob. & \\
\hline Mull Hvootbesu & & & & \\
\hline & & & & \\
\hline [NT does not Granger Cause TA EA & & $\mathbf{0 . 3 6 4 6 1}$ & $\mathbf{0 . 6 9 8 6}$ & \\
\hline does not Granger Cause INT & & $\mathbf{0 . 7 7 6 6 5}$ & $\mathbf{0 . 4 7 2 2}$ & \\
\hline & & & & \\
\hline & & & & \\
\hline [NFL doea not (banner Cause TA. & & $\mathbf{0 . 3 6 9 7 4}$ & 0.6951 & \\
\hline & & & & \\
\hline & & & & \\
\hline LD docs not Granger Cause TA. & & $\mathbf{2 . 8 4 8 6 5}$ & $\mathbf{0 . 0 7 9 4}$ & \\
\hline & & & & \\
\hline
\end{tabular}

\section{Granger Causality Test}

\section{Policy Implication}

From the research output, it has been established that deregulation policy is favorable to the robust functioning and performance of commercial banks in Nigeria. Hence deregulation policy needs to be strengthened to accommodate frequent volatility in the country's financial sector.

From the Granger Causality Output, there is unidirectional Causality between Total Assets (TA) and Loans and Advances (LD). Hence Total Assets (TA) Granger Causes Loans and Advances (LD) at 5\% level of significances, The Granger Causality test could not establish relationship between interest rate (INT), Inflation (INFL) and Total Assets (TA), at 5\% level of significance.

\section{CONCLUSION AND RECOMMENDATIONS}

From the analysis conducted, it is established that there is a nexus between interest rate deregulation and performance of deposit money banks measured by banks total assets. This shows the highly significant position of interest rates in the business of the banks. This calls for support from the regulatory bodies to see that such strengthens rather than weakens the deposit money banks. The researcher also notes the inability to establish forecasting relationships between interest rate and Banks Total Assets. From the forgoing, the research recommends that;

Interest rate deregulation policy should be maintained to enable the nation to enjoy a robust financial sector capable of providing the financial facilities needed for economic development of the nation. Hence the CBN should consider not frequently changing the MPR (monetary 
policy rate) and CRR (Cash reserve ratio) which most of the time influence interest rate peg of the deposit money banks.

A 6.5 percent increase in Total Asset with a change in interest rate means that it's empirically right to say that Nigerian banks use the advantage of the deregulation policy to charge extremely high rates on loans, which means that the borrower may not actually be expanding their investment in the real sector. Hence the CBN should consider a single digit monetary policy rate to help drive down the interest rate charged by deposit money banks so that the real sector can have a good benefit of the financial facilities they access. Such will go a long way to ensure steady economic growth in Nigeria.

The unidirectional Causality between Total Assets and Loans and Advances of banks shows the reason why commercial banks cannot provide facilities to capital intensive projects. It is because total assets of some of the banks are not enough to finance huge projects. Thus, the CBN should make provision for the establishment of specialized banks run under public private partnership to provide credit facilities for capital intensive projects.

\section{Limitations and Future Research}

The research is constructively limited to the study of interest rate deregulations in Nigeria for the period of 1988-2018. This research can also be extended to the other financial institutions in the country to assess the general effect of interest rate deregulation in the financial sector of the country since the deposit money banks have constant interaction with other financial institutions in the country.

\section{REFERENCES}

Afza, A., Raja, R., Imran, U. C. \& Saima, S. (2018). Interest Rate and Financial Performance of Banks in Pakistan, International Journal of Applied Economics, Finance and Accounting Vol. 2, No. 1, pp. 1-7.

Alhassan, M. D., Anokye, F. K and Gakpetor, E.D. (2018).THE IMPACT OF INTEREST RATE SPREAD ON BANK PROFITABILITY IN GHANA, European Journal of Business, Economics and Accountancy Vol. 6, No. 1.

CBN (2017), Statistical Bulletin. Abuja, Nigeria.

Central Bank of Nigeria Communique No. 121 of the Monetary Policy .Retrieved fromhttps://www. cbn.gov. ng.

Central Bank of Nigeria Monetary Policy Decisions .Retrieved from https://www.cbn.gov.ng/MonetaryPolicy/decisions.asp.

Egbetunde, T., Ayinde, T. O. and Balogun, A.A.' (2017).Interest Rate Liberalization, Financial Development and Economic Growth in sub-Saharan African Economies, African Journal of Economic Review, Volume V, Issue II.

Eke,F. A., Eke, I.C. and Inyang, G.I. (2015). Interest rate and commercial banks' lending operations in N igeria: A structural break analysis using chow test, Global Journal ofSocial Sciences Vol 14. Guesmi, S. (2015). The Impact of Financial Liberalization on the Performance of the Algerian Public Banks, PAD. thesis submitted to University ofTlemcen, Faculty of Economics and Management. Loanable-funds-theory.Retrieved from http://www.economicsdiscussion.net/theories/loanablefunds- theory-withdiagram/7504. 
Makinde, H. O. (2016). Effect of Interest Rate on Commercial Bank Deposits in Nigeria, Proceeding ofthe First American Academic Research Conference on Global Business, Economics, Finance and Social Sciences (AAR 16 New York Conference) ISBN: 978-1943579-50-1 New York, USA.. Paper ID.N644.

Manamba, E. (2014). An Empirical Analysis of Interest Rate Spreads in Tanzania, Asian Journal of Research in Banking and Finance Vol. 4, No. 10.

Matemilola, B.T., Bany-Ariffm A.N and Muhtar, F.E. (2014). The impact of monetary policy on bank lending rate in South Africa, Borsa Istanbul Review.

Odeke, S. and Odongo, J. (2014).Interest Rate Risk Exposure and Financial Performance of Commercial Banks InUganda, Research Journal of Finance and Accounting ISSN 2222-1697 (Paper) ISSN 2222-2847(Online) Vol.5, No.2.

Pesaran, M.H., Shin, Y. and Smith, R. (2001), "Bounds testing approaches to the analysis of level relationships". .^.' Journal of Applied Econometrics 16(3): 289-326. Structureconduct-performance-paradigm.Retnec/ from https://policonomics.com/structureconductperformancej $\mathrm{P}<2 \mathrm{~m}<7 / \mathrm{gyw} /$

Ubesie, M. (2016).The Effect of Financial Sector Liberalization on Economic Growth in Nigeria, International Journal of Finance and Accounting, Vol. 5No. 4.

Udoka, C.l,Agwenjang, A. R. and Arzizeh, T. T. (2012). An Empirical Analysis of the Effect of Interest Rate Management Policies in Nigeria, IOSR Journal of Business and Management (IOSR-JBM) ISSN: 2278-487X. Volume 4, Issue 6.

Ugwuanyi,U. (2012). The Interest Rate Deregulation and Bank Lending in Nigeria, Journal of Economics andSustainableDevelopment 2222-1700 (Paper) ISSN2222-2855 (Online) Vol.3, No. 12. 